\title{
Susceptibility of Some Eastern Forest Species to Phytophthora ramorum
}

\author{
Paul W. Tooley, United States Department of Agriculture-Agricultural Research Service, Foreign Disease-Weed \\ Science Research Unit, Ft. Detrick, MD 21702-5023; and Kerrie L. Kyde, Department of Plant Sciences, University \\ of Rhode Island, Kingston, RI 02881
}

\begin{abstract}
Tooley, P. W., and Kyde, K. L. 2007. Susceptibility of some Eastern forest species to Phytophthora ramorum. Plant Dis. 91:435-438.

We tested some common Eastern forest species for their reaction to stem and leaf inoculation with Phytophthora ramorum, the pathogen that causes sudden oak death. Stem lesions were produced on inoculated seedlings of 12 Eastern forest species following 72 to 76 days of incubation in a containment greenhouse cubicle at $20^{\circ} \mathrm{C}$. Chestnut oak (Quercus prinus) and white oak $(Q$. alba) were followed by northern red oak ( $Q$. rubra) in susceptibility to stem inoculation. Sugar maple (Acer saccharum) and black walnut (Juglans nigra) were more resistant to stem inoculation than most of the oak species tested. P. ramorum was isolated on selective medium at distances of up to $8 \mathrm{~mm}$ from stem lesion margins. Foliar lesions were observed within 7 days when seedlings were inoculated with 5,000 sporangia/ml followed by incubation at $20^{\circ} \mathrm{C}$ in a dew chamber. Chestnut oak was followed by tanoak (Lithocarpus densiflorus) and coast live oak (Q. agrifolia) in susceptibility to P. ramorum by foliar inoculation. Chestnut oak, an ecologically important species in parts of the Eastern United States, emerged as the most susceptible host tested in both stem and foliar inoculations. The results indicate that, under controlled conditions, $P$. ramorum is able to infect some important Eastern forest species and cause lesions on stems and foliage. It remains to be determined whether infection of these species by P. ramorum would occur under natural conditions.
\end{abstract}

Phytophthora ramorum Werres, De Cock \& Man in't Veld (31) causes sudden oak death, a disease that has killed large numbers of tanoak (Lithocarpus densiflorus (Hook \& Arn.) Rehd.), coast live oak (Quercus agrifolia Neé), and California black oak ( $Q$. kelloggii Newb.) along the California coast and in a $21.5-$ mile $^{2}$ area of southwestern Oregon $(4,7,23,24)$. The Animal and Plant Health Inspection Service (APHIS) of the United States Department of Agriculture now lists over 100 species of regulated hosts and plants associated with $P$. ramorum. The list continues to expand as more susceptible species are discovered $(3,4,10,14,20)$, including two important conifer species $(3,17)$.

Most forest damage caused by $P$. ramorum has occurred in California and a small portion of southwestern Oregon $(8,23)$; however, there is concern that the pathogen could move eastward on ornamental host plants shipped within the nurs-

Corresponding author: P. W. Tooley

E-mail: paul.tooley@ars.usda.gov

Current address of K. L. Kyde: Maryland Department of Natural Resources, Annapolis, MD 21401.

Accepted for publication 20 October 2006.

doi:10.1094/PDIS-91-4-0435

This article is in the public domain and not copyrightable. It may be freely reprinted with customary crediting of the source. The American Phytopathological Society, 2007. ery industry (28). If spread in this manner, it could threaten the vast oak forests present in many Eastern states $(27,30)$. $P$. ramorum has been shown in laboratory studies to have the ability to grow and sporulate over a wide range of temperatures $(7,31)$, indicating that it may have a high potential for establishment in new regions characterized by more extreme environmental conditions than are present in areas where it is now established.

In March 2004, P. ramorum was identified on camellias at a large commercial nursery in California that had shipped potentially infected plants to garden centers in 39 states (28). Surveys have not yet detected $P$. ramorum in Eastern forests (22). In the United Kingdom and The Netherlands, trees infected with $P$. ramorum have been in close association with infected rhododendrons, providing some evidence that this mode of transmission is possible $(1,15)$. Some of the affected tree species are important Eastern U.S. natives, southern red oak ( $Q$. falcata Michx.) in the United Kingdom (1), and northern red oak in The Netherlands (J. Jones, personal communication). The latter species is now on the APHIS list of plants associated with $P$. ramorum.

Until 2003, only oak in the red oak group (section Lobatae) were found infected by $P$. ramorum in the wild $(19,24)$. Rizzo et al. (25) performed artificial inoculation of selected oak species to determine their reaction to $P$. ramorum. Two important Eastern oak species, northern red oak
(Q. rubra L.) and pin oak (Q. palustris Muenchh.), were found to be susceptible to artificial stem inoculation (25). Hansen et al. (9) used various artificial inoculation methods to assess reactions of 42 native Oregon tree and shrub species and 3 species not native to Oregon, including American chestnut (Castanea dentata (Marsh.) Borkh.), northern red oak, and pin oak.

In 2003, holm oak (Q. ilex L.), in the white oak group (section Quercus), was found naturally infected with $P$. ramorum in Cornwall, United Kingdom (15). Reactions of European oak to $P$. ramorum have been assessed by inoculation of logs (2), whereas a detached leaf assay was used by Denman et al. (6) to assess reactions of 11 conifers and 23 broad-leaved tree species important in the United Kingdom.

Studies of reactions to $P$. ramorum by important Eastern oak species in both the red and white groups are needed to assess the likelihood that Eastern forest species may become infected by $P$. ramorum, serve as inoculum reservoirs for the pathogen, and potentially spread the disease further in Eastern forest ecosystems. Knowledge of the relative susceptibility to $P$. ramorum of various oak species could refine forest surveys by focusing effort on species known to be most susceptible when artificially inoculated. Such work also would provide knowledge about the rate at which disease potentially could increase on specific native oak trees and spread in forest ecosystems. Such studies cannot be performed at most research institutions, or under natural conditions in the Eastern United States due to quarantine restrictions, which prevent importation and experimentation with $P$. ramorum in noninfested areas. We used specialized containment greenhouse facilities at Ft. Detrick, MD to assess the disease reactions of 11 important Eastern forest species to $P$. ramorum, including assessments of the foliar susceptibility of eight oak species.

\section{MATERIALS AND METHODS}

Bare root oak seedlings, 2 to 3 years old, were obtained and grown in 1- and 2gallon (3.78- and 7.56-liter) nursery pots in Fafard 52 planting mix (Conrad Fafard, Inc., Agawam, MA), a mixture of processed pine bark (55\%), sphagnum peat moss $(30 \%)$, perlite $(10 \%)$, and vermiculite $(5 \%)$. Trees initially were maintained in a conventional greenhouse and moved to a Biosafety Level 3 containment facility at 
Ft. Detrick, MD, where they were placed in a temperature-controlled greenhouse cubicle at $20^{\circ} \mathrm{C}$.

Stem inoculations. Selected oak species included seedlings of coast live oak $(Q$. agrifolia), northern red oak (Q. rubra), white oak $(Q$. alba), cherrybark oak $(Q$. pagoda Raf.), chestnut oak ( $Q$. prinus), laurel oak ( $Q$. laurifolia Michx.), live oak (Q. virginiana $\mathrm{P}$. Mill.), water oak ( $Q$. nigra L.), and willow oak (Q. phellos L.).

Coast live oak, northern red oak, laurel oak, water oak, and willow oak are members of section Lobatae, the red oak group, whereas white oak, chestnut oak, and live oak are in section Quercus, the white oak group $(18,21)$. Two additional Eastern forest species, sugar maple (Acer saccharum) and black walnut (Juglans nigra), also were included in these studies. Tanoak was not included in stem inoculations because the stem diameters were too small.

Seedlings were inoculated with $P$. ramorum isolate Pr-6 $(12,24,25)$ isolated from coast live oak in California. With a scalpel, a 6-mm-diameter plug from a 3- to 4-week-old $P$. ramorum colony growing on $20 \% \mathrm{~V} 8$ juice agar in darkness at $20^{\circ} \mathrm{C}$ was placed in a wound cut, approximately 4 $\mathrm{mm}$ deep, into the stem approximately 5 $\mathrm{cm}$ above the soil line. Inoculation wounds were covered with Parafilm to prevent desiccation. Control seedlings received a 6-mm plug of V8 juice agar only. Seedlings then were incubated in a containment greenhouse cubicle at $20^{\circ} \mathrm{C}$ for 72 to 76 days, after which results were assessed. Due to restrictions on the size of the greenhouse cubicles, tree species were tested in groups, 25 seedlings per species, with coast live oak included in each experiment as a known susceptible standard. Experiments 1 and 2 included white, red, chestnut, and cherrybark oak plus coast live oak susceptible standards, and were run for 72 and 75 days, respectively. Experiments 3 and 4 included live and laurel oak and coast live oak standards and were run for 76 and 75 days, respectively. Experiments 5 and 6 included water oak, willow oak, sugar maple, black walnut, and coast live oak standards and both were run for 73 days.

Upon completion of the experiments, stem sections containing $P$. ramorum lesions were excised and the outer $1 \mathrm{~mm}$ containing the bark was removed using a scalpel. Lesion areas were recorded by tracing the lesion margins with black marker onto $4-\mathrm{cm}^{2}$ of cheesecloth wrapped around each seedling's stem. The lesion margins were easily visible through the holes in the cheesecloth. The cheesecloth squares then were removed and flattened on a piece of plain white paper. Lesion margin impressions were transferred through the cheesecloth onto the paper using a black marker, which produced a series of dots on the paper. The cheesecloth then was removed and the marks on the paper connected, providing an outline of the lesion margin. Lesion areas were measured from these transferred images using ASSESS image analysis software (16). Because stem diameters varied for different tree species (from a mean of 5.76 $\mathrm{mm}$ in diameter for inoculated seedlings of coast live oak up to $10.76 \mathrm{~mm}$ in diameter for laurel oak), lesion area measurements also were adjusted by dividing lesion areas by the stem diameter on a per plant basis.

In two experiments, five tissue pieces (approximately $1 \mathrm{~mm}^{2}$ ) were excised with a sterile scalpel from the lesion margins and at distances of $2,4,6$, and $8 \mathrm{~mm}$ from the lesion margins for 10 randomly selected seedlings each of chestnut oak, northern red oak, white oak, cherrybark oak, and coast live oak. Thus, each sampling produced 1,250 tissue pieces ( 5 exci-

Table 1. Lesion areas produced 72 to 76 days following stem-inoculation of 2- to 3-year-old seedlings of 11 forest species with Phytophthora ramorum ${ }^{\mathrm{w}}$

\begin{tabular}{lccc}
\hline Species & $\boldsymbol{n}^{\mathbf{x}}$ & Lesion area $\left(\mathbf{c m}^{\mathbf{2}}\right)$ & Adjusted lesion area $\left(\mathbf{c m}^{\mathbf{2}}\right)^{\mathbf{y}}$ \\
\hline Chestnut oak (Quercus prinus) & 50 & $3.20 \mathrm{a}$ & $3.29 \mathrm{a}$ \\
White oak (Quercus alba) & 50 & $2.80 \mathrm{~b}$ & $3.18 \mathrm{a}$ \\
Northern red oak (Quercus rubra) & 50 & $2.16 \mathrm{c}$ & $2.08 \mathrm{~b}$ \\
Laurel oak (Quercus laurifolia) & 50 & $1.76 \mathrm{~d}$ & $1.62 \mathrm{c}$ \\
Cherrybark oak (Quercus pagoda) & 50 & $1.55 \mathrm{~d}$ & $1.82 \mathrm{bc}$ \\
Willow oak (Quercus phellos) & 50 & $1.16 \mathrm{e}$ & $1.25 \mathrm{~d}$ \\
Water oak (Quercus nigra) & 50 & $1.16 \mathrm{e}$ & $1.26 \mathrm{~d}$ \\
Black walnut (Juglans nigra) & 50 & $1.10 \mathrm{e}$ & $1.16 \mathrm{de}$ \\
Live oak (Quercus virginiana) & 50 & $1.08 \mathrm{e}$ & $1.18 \mathrm{~d}$ \\
Sugar maple (Acer saccharum) & 50 & $0.94 \mathrm{e}$ & $0.91 \mathrm{e}$ \\
Coast live oak (Quercus agrifolia) & 150 & $0.68 \mathrm{f}$ & $1.29 \mathrm{~d}$ \\
Controls & 130 & $0.15 \mathrm{~g}$ & $0.24 \mathrm{f}$ \\
\hline
\end{tabular}

${ }^{\mathrm{w}}$ Seedlings were inoculated by placing an agar plug containing mycelium in a wound in the stem, wrapping the site with Parafilm to prevent desiccation, and incubating in a greenhouse cubicle at $20^{\circ} \mathrm{C}$ for 72 to 76 days. Means within a column followed by the same letter do not differ significantly by the Waller-Duncan K-ratio $t$ test $(k$ ratio $=100)$.

${ }^{x}$ Two sets of 25 seedlings were inoculated for each species tested, except for coast live oak, which was included as a known susceptible standard; in total, 150 coast live oak seedlings were inoculated (25 per experiment in each of six experiments).

${ }^{y}$ Adjusted by dividing lesion area by stem diameter for each inoculated seedling.

${ }^{\mathrm{z}}$ Seedlings in each experiment that were inoculated with plugs of V8 juice agar with no P. ramorum present. sions $\times 5$ distances $\times 10$ seedlings $\times 5$ oak species), which were plated onto PARP selective medium (13) and incubated at $20^{\circ} \mathrm{C}$ in darkness for 7 days. The percentage of the plated tissue pieces from which $P$. ramorum was isolated was recorded in each experiment. An additional measure of $P$. ramorum recovery was the percentage of stems, out of the total of 50 assayed (10 seedlings $\times 5$ oak species) per experiment, from which $P$. ramorum grew from one or more tissue pieces at each distance from the lesion margins. Data were analyzed using the SAS statistical package (26).

Foliar inoculations. Seedlings of coast live oak, northern red oak, white oak, cherrybark oak, chestnut oak, live oak, laurel oak, and tanoak were inoculated by placing branches containing at least 15 leaves each into a plastic bag containing approximately $100 \mathrm{ml}$ of a suspension of $P$. ramorum isolate Pr-6 at 5,000 sporangia/ml and shaking. Sugar maple and black walnut were not included in foliar inoculations due to the large size of the trees relative to the dew chamber size. Seedlings then were placed in a dew chamber at $20^{\circ} \mathrm{C}$ in darkness for 7 days. The amount of infected leaf tissue was determined by detaching 15 randomly selected inoculated leaves, scanning them on a flatbed scanner, and measuring leaf and lesion areas with ASSESS image analysis software (16). Two 15-leaf replicates were performed with each oak species tested, and coast live oak replicates were included with each set of inoculated plants. Data were analyzed using the SAS statistical package (26).

\section{RESULTS}

Lesion areas of stem-inoculated seedlings ranged from 0.68 to $3.20 \mathrm{~cm}^{2}$ (Table 1). No trees were girdled or killed. The two species with the largest stem lesion areas were chestnut oak and white oak, followed by northern red oak (Table 1). Following adjustment for stem diameter, species rankings remained relatively consistent, with chestnut oak and white oak still having the largest lesions. The species with smallest lesions following adjustment for stem diameter were sugar maple, black walnut, and live oak. Prior to adjustment, coast live oak appeared to have the smallest lesions. After adjustment, however, it ranked in the middle of the range of lesion sizes (Table 1).

$P$. ramorum was reisolated successfully from all species tested and never isolated from seedlings inoculated with V8-juice agar alone. $P$. ramorum was recovered most frequently at lesion margins and at a distance of $2 \mathrm{~mm}$ from lesion margins (Table 2). At 4, 6, and $8 \mathrm{~mm}$ from lesion margins, recovery percentages were significantly reduced from those observed at $2 \mathrm{~mm}$ (Table 2). No significant differences among species were noted in recovery of $P$. ramorum. 
Following foliar inoculation, percent disease ranged from $0.5 \%$ for white oak to $17 \%$ for chestnut oak. As observed for stem inoculation, chestnut oak showed the highest level of foliar infection caused by $P$. ramorum (Table 3 ). Tanoak, generally considered the most susceptible host under natural conditions in California, sustained the second highest percent foliar infection $(13.2 \%)$ after chestnut oak. Six of the seven Quercus spp. included in foliar inoculations showed low levels of foliar infection and did not differ significantly from one another (Table 3). P. ramorum was reisolated successfully from foliar lesions originating from all eight species tested in foliar inoculations.

\section{DISCUSSION}

Our results indicate that some Eastern forest species can sustain both foliar and stem infection and lesion development by $P$. ramorum following artificial inoculation. Our results provide the first indication of moderate to high susceptibility of white oak group species in the United States. In our experiments, two members of the white oak group, white oak and chestnut oak, showed the largest stem lesion areas compared with the other species tested, although a third, live oak, proved to be among the more resistant species tested.

Until 2003, no oak species outside the red oak group had been found naturally infected in the wild in either the United States or the United Kingdom $(15,19,24)$. In 2003, holm oak was found to be in-

Table 2. Percent recovery of Phytophthora ramorum from five oak species on PARP selective medium at various distances from lesion margins $^{\mathrm{w}}$

\begin{tabular}{lcc}
\hline Distance $(\mathbf{m m})^{\mathbf{x}}$ & ${\text { Tissue }(\%)^{\mathbf{y}}}$ & ${\text { Stems }(\%)^{\mathbf{z}}}$ \\
\hline 0 & $90.2 \mathrm{a}$ & $99.0 \mathrm{a}$ \\
2 & $75.2 \mathrm{~b}$ & $99.0 \mathrm{a}$ \\
4 & $5.2 \mathrm{c}$ & $26.0 \mathrm{~b}$ \\
6 & $2.8 \mathrm{~cd}$ & $12.0 \mathrm{c}$ \\
8 & $0.8 \mathrm{~d}$ & $4.0 \mathrm{~d}$ \\
\hline
\end{tabular}

${ }^{\text {w }}$ Recovery of $P$. ramorum from tissue taken from lesion margins and at distances of $0,2,4$, 6 , and $8 \mathrm{~mm}$ from lesion margins. Five $1-\mathrm{mm}-$ diameter tissue pieces were removed with a sterile scalpel at each distance from lesion margins and plated onto PARP agar medium (13). Results are means of 50 sampled stems (10 stems $\times 5$ oak species) from each of two experiments. No significant differences in recovery were noted between different oak species; therefore, results were combined over species. Means followed by the same letter do not differ significantly by the Waller-Duncan $k$-ratio $t$ test $(k$ ratio $=100)$.

${ }^{x}$ Distance from lesion margin $(\mathrm{mm})$.

y Percent tissue pieces with $P$. ramorum. Five tissue pieces were removed and plated on PARP medium at each distance from the lesion margin.

${ }^{z}$ Percentage of stems with $P$. ramorum out of the total of 100 assayed (two experiments, 50 stems each), from which $P$. ramorum grew from one or more tissue pieces at each distance from the lesion margins. fected in Britain (15) and canyon live oak (Q. chrysolepis Liebm.), a member of the intermediate or golden cup group (section Protobalanus) was found infected in the wild in California (20). Even in previous artificial inoculations, white oak group members tested were more resistant than red oak group members $(9,25)$. Rizzo et al. (25) found that valley oak ( $Q$. lobata Neé) and blue oak (Q. douglasii Hook \& Arn.) tested by stem inoculation were more resistant to $P$. ramorum than members of the red oak group. Hansen et al. (9) reported that lesions averaging $3 \mathrm{~cm}$ in length formed on northern red oak ( $Q$. rubra) following 3 weeks of incubation, whereas Oregon white oak (Q. garryana Dougl. ex Hook.) showed a mean stem lesion length of only $0.8 \mathrm{~cm}$ and appeared to have relatively resistant foliage. Our results from greenhouse inoculation of members of both red and white groups following over 70 days of incubation indicate that infection may occur under greenhouse conditions within members of both groups of oak species.

Stem diameter adjustment changed coast live oak from the most resistant species to one with an intermediate ranking for susceptibility to $P$. ramorum by stem inoculation. Young coast live oak seedlings have comparatively narrow stems; therefore, unadjusted estimates of lesion area will tend to be small compared with those observed on species with much larger stem diameter. After adjustment, there were five species with stem lesion areas significantly greater than those observed on coast live oak. Coast live oak is one of the primary hosts of $P$. ramorum in California, indicating that at least some Eastern oak species could sustain levels of infection equal to or greater than that observed on coast live oak if $P$. ramorum became established in the Eastern United States.

$P$. ramorum was recovered from lesion margins and from woody tissue up to 8 $\mathrm{mm}$ outside lesion margins. This indicates that the pathogen can survive in oak host tissue for several months, both near and at some distance from actual lesions. Hüberli et al. (11) also reported high $P$. ramorum recovery rates near the lesions of coast live oak, and approximately $30 \%$ recovery at $0.5 \mathrm{~cm}$ distance from lesion margins.

Chestnut oak was also the most susceptible species by foliar inoculation. This species is a dominant tree in the Piedmont and Mountain regions of North Carolina, and its acorns are an important food source for wildlife. The area it covers is in the high-risk category for sudden oak death establishment (27,30). Thus, Eastern U.S. forest surveys might make this a priority species to examine for early evidence of $P$. ramorum infection and establishment in new areas. In North Carolina forest ecosystems, there also are frequent associations of chestnut oak with other species found to have high susceptibility to $P$. ramorum, such as Kalmia latifolia L. (mountain laurel) and various Rhododendron spp. (29), and such areas could serve as infection foci should the disease become established in the region.

The role of foliar infection of oak trees in the epidemiology of sudden oak death is unknown. Foliar lesions are not commonly reported in descriptions of the disease occurring on oak $(4,24)$. However, foliar infection of sweet chestnut $(C$. sativa $\mathrm{P}$. Mill.) on epicormic shoots and young leaves was reported by Denman et al. (5) in the United Kingdom and laboratory experiments showed that the pathogen is able to sporulate on leaves. The role of foliar lesions on oak in producing inoculum that may spread the disease to new areas or infect adjoining trees is unknown and should be explored further.

In summary, we found that $P$. ramorum, under containment greenhouse conditions, was able to cause lesions in stems of seedlings of 10 different Eastern forest species and on foliage of 6 oak species important in the Eastern United States. Extrapolation of results from seedlings of these species to potential reactions of adult trees must be done with care. Tests of reactions on adult plants and using additional isolates, as well as additional research on the epidemiology of the disease, are needed to assess the true

Table 3. Results of foliar inoculation of eight oak species with Phytophthora ramorum

\begin{tabular}{lcc}
\hline Species & $\boldsymbol{n}^{\mathbf{y}}$ & Disease (\%) $^{\mathbf{z}}$ \\
\hline Quercus prinus (Chestnut oak) & 26 & $17.0 \mathrm{a}$ \\
Lithocarpus densiflorus (Tanoak) & 25 & $13.2 \mathrm{a}$ \\
Quercus alba (White oak) & 22 & $0.5 \mathrm{~b}$ \\
Quercus rubra (Northern red oak) & 29 & $2.1 \mathrm{~b}$ \\
Quercus pagoda (Cherrybark oak) & 13 & $0.2 \mathrm{~b}$ \\
Quercus laurifolia (Laurel oak) & 18 & $1.6 \mathrm{~b}$ \\
Quercus virginiana (Live oak) & 9 & $0.6 \mathrm{~b}$ \\
Quercus agrifolia (Coast live oak) & 40 & $2.8 \mathrm{~b}$ \\
\hline
\end{tabular}

y Number of infected leaves out of 30 inoculated leaves ( 15 leaves $\times 2$ experiments) for which lesion area was determined using ASSESS image analysis software. Seedlings were dipped in suspensions containing $P$. ramorum isolate Pr-6 at 5,000 sporangia/ml, then incubated in a dew chamber at $20^{\circ} \mathrm{C}$ in darkness for 7 days. Coast live oak was included as a known susceptible standard with each group of inoculated plants; hence, there were 40 total leaves inoculated instead of 30 as for other species.

${ }^{\mathrm{z}}$ Percent disease refers to lesion area as a percentage of total leaf area and only infected leaves were included in the analyses. Means followed by the same letter do not differ significantly by the WallerDuncan $k$-ratio $t$ test $(k$ ratio $=100)$. 
likelihood that $P$. ramorum will infect Eastern forest species under natural conditions.

\section{ACKNOWLEDGMENTS}

We thank S. Oak, United States Forest Service, for valuable assistance in providing oak trees used in these studies, as well as research advice; S. Anagnostakis for providing oak, sugar maple, and black walnut trees; D. Struve, who provided key information on growing oak in the greenhouse; $\mathrm{C}$. Cavin for help in processing plants into the containment facility and assistance in maintaining greenhouse cubicles; and B. McPherson for access to his in-press manuscript and for helpful observations.

\section{LITERATURE CITED}

1. Brasier, C. M., Denman, S., Rose, J., Kirk, S. A., Hughes, K. J. D., Griffin, R. L., Lane, C. R., Inman, A. J., and Webber, J. F. 2004. First report of ramorum bleeding canker on Quercus falcata, caused by Phytophthora ramorum. Plant Pathol. 53:804.

2. Brasier, C. M., Rose, J., Kirk, S. A., and Webber, J. F. 2002. Pathogenicity of Phytophthora ramorum isolates from North America and Europe to bark of European Fagaceae, American Quercus rubra and other forest trees. Sudden Oak Death Science Symposium, Monterey, CA.

3. Davidson, J. M., Garbelotto, M., Koike, S. T., and Rizzo, D. M. 2002. First report of Phytophthora ramorum on Douglas-fir in California. Plant Dis. 86:1274.

4. Davidson, J. M., Werres, S., Garbelotto, M., Hansen, E. M., and Rizzo, D. M. 2003. Sudden oak death and associated diseases caused by Phytophthora ramorum. Online. Plant Health Progress doi:10.1094/PHP-2003-0707-01-DG.

5. Denman, S. Kirk, S. A., Brasier, C. M., Hughes, K. J. D., Griffin, R., Hobdon, E., and Webber, J. F. 2005. Foliar infection of sweet chestnut (Castanea sativa) by Phytophthora ramorum in the UK. Plant Pathol. 54:581.

6. Denman, S., Kirk, S. A. Brasier, C. M., and Webber, J. F. 2005. In vitro leaf inoculation studies as an indication of tree foliage susceptibility to Phytophthora ramorum in the UK. Plant Pathol. 54:512-521.

7. Englander, L., Browning, M., and Tooley, P. W. 2006. Growth and sporulation of Phytophthora ramorum in vitro in response to temperature and light. Mycologia 98:365-373.
8. Goheen, E. M., Hansen, E. M., Kanaskie, A., McWilliams, M. G., Osterbauer, N., and Sutton, W. 2002. Sudden oak death caused by Phytophthora ramorum in Oregon. Plant Dis. 86:441.

9. Hansen, E. M., Parke, J. L., and Sutton, W. 2005. Susceptibility of Oregon forest trees and shrubs to Phytophthora ramorum: a comparison of artificial inoculation and natural infection. Plant Dis. 89:63-70.

10. Henricot, B., and Prior, C. 2004. Phytophthora ramorum, the cause of sudden oak death or ramorum leaf blight and dieback. Mycologist 18:151-156.

11. Hüberli, D., Harnik, T., Meshriy, M., Miles, L., and Garbelotto, M. Phenotypic variation among Phytophthora ramorum isolates from California and Oregon. Proc. SOD Science Symposium, January 2005, Monterey, CA. In press.

12. Ivors, K., Hayden, K., Bonants, P. M., Rizzo, D. M., and Garbelotto, M. 2004. AFLP and genetic analyses of North American and European populations of Phytophthora ramorum. Mycol. Res. 108:378-392.

13. Jeffers, S. N., and Martin, S. B. 1986. Comparison of two media selective for Phytophthora and Pythium species. Plant Dis. 70:1038-1043.

14. Jones, J. 2005. APHIS List of Plants Regulated and Associated with Phytophthora ramorum. USDA-APHIS (online publication).

15. Kirk, S. A., Brasier, C. M., Barton, V. C., Hughes, K. J. D., and Webber, J. F. 2005. Phytophthora ramorum on Quercus ilex in the United Kingdom. Plant Dis. 89:1241.

16. Lamari, L. 2002. ASSESS: Image Analysis Software for Plant Disease Quantification. American Phytopathological Society Press, St. Paul, MN.

17. Maloney, P. E., Rizzo, D. M., Koike, S. T., Harnik, T. Y., and Garbelotto, M. 2002. First report of Phytophthora ramorum on coast redwood in California. Plant Dis. 86:1274.

18. Manos, P. S., Doyle, J. J., and Nixon, K. C. 1999. Phylogeny, biogeography, and processes of molecular differentiation in Quercus subgenus Ouercus (Fagaceae). Mol. Phylogenet. Evol. 12:333-349.

19. McPherson, B. A., Mori, S. R., Wood, D. L., Storer, A. J., Svihra, P., Maggi Kelly, N., and Standiford, R. B. 2005. Sudden oak death in California: disease progression in oaks and tanoaks. For. Ecol. Manage. 213:71-89.

20. Murphy, K., and Rizzo, D. M. 2003. First report of Phytophthora ramorum on canyon live oak in California. Plant Dis. 87:315.

21. Nixon, K. C. 1993. Infrageneric classification of Quercus (Fagaceae) and typification of sectional names. Ann. Sci. For. 50(Suppl.1):2534.

22. Oak, S. W., Smith, W. D., and Tkacz, B. M. Phytophthora ramorum detection surveys for forests in the United States. Proc. SOD Science Symposium, January 2005, Monterey, CA. In press

23. Rizzo, D. M., and Garbelotto, M. 2003. Sudden oak death: endangering California and Oregon forest ecosystems. Front. Ecol. Environ. 1:197-204.

24. Rizzo, D. M., Garbelotto, M., Davidson, J. M., Slaughter, G. W., and Koike, S. T. 2002. Phy tophthora ramorum as the cause of extensive mortality of Quercus spp. and Lithocarpus densiflorus in California. Plant Dis. 86:205214.

25. Rizzo, D. M., Garbelotto, M., Davidson, J. M. Slaughter, G. W., and Koike, S. T. 2002. Phytophthora ramorum and sudden oak death in California: I. Host relationships. Pages 733 740 in: 5th Symp. California Oak Woodlands. R. Standiford and D. McCreary, eds. U. S. For Serv. Gen. Tech. Rep. PSW-GTR-184.

26. SAS Institute. 1999. SAS/STAT User's Guide, Version 8, Volumes 1, 2, and 3. SAS Publishing, Cary, NC.

27. Smith, W. D., Coulston, J. W., Goheen, E M., Sapio, F., Gottschalk, K. W., Frankel, S., Dunn, P., and Tkacz, B. M. 2002. Development of a National Survey Protocol for Detection of Phytophthora ramorum. Sudden Oak Death Science Symposium, Monterey, CA.

28. Stokstad, E. 2004. Nurseries may have shipped sudden oak death pathogen nationwide. Science 303:1959.

29. Tooley, P. W., Kyde, K. L., and Englander, L. 2004. Susceptibility of selected ericaceous ornamental host species to Phytophthora ramorum. Plant Dis. 88:993-999.

30. Venette, R. C., and Cohen, S. D. 2006. Potential climatic suitability for establishment of Phytophthora ramorum within the contiguous United States. For. Ecol. Manage. 231:18-26.

31. Werres, S., Marwitz, R., Man In'T Veld, W., De Cock, Arthur W. A. M., Bonants, P. J. M., De Weerdt, M., Themann, K., Ilieva, E., and Baayen, R. P. 2001. Phytophthora ramorum p. nov., a new pathogen on Rhododendron and Viburnum. Mycol. Res. 105:1155-1165. 